University of Chicago Law School

Chicago Unbound

\title{
Construing the Uniform Division of Income for Tax Purposes Act: Reflections on the Illinois Supreme Court's Reading of the Throwback Rule
}

Walter Hellerstein

Follow this and additional works at: https://chicagounbound.uchicago.edu/journal_articles

Part of the Law Commons

\section{Recommended Citation}

Walter Hellerstein, "Construing the Uniform Division of Income for Tax Purposes Act: Reflections on the Illinois Supreme Court's Reading of the Throwback Rule," 45 University of Chicago Law Review 768 (1978).

This Article is brought to you for free and open access by the Faculty Scholarship at Chicago Unbound. It has been accepted for inclusion in Journal Articles by an authorized administrator of Chicago Unbound. For more information, please contact unbound@law.uchicago.edu. 


\title{
Construing the Uniform Division of Income for Tax Purposes Act: Reflections on the Illinois Supreme Court's Reading of the "Throwback" Rule
}

\author{
Walter Hellerstein $\dagger$
}

In the state tax field, decisions of state tribunals generally deal with statutory issues of little precedential significance outside the jurisdiction in which they arise. Even cases raising federal constitutional issues normally do not disturb the analytical framework established by the Supreme Court and thus are more appropriately treated in the footnotes to a discussion of that Court's opinions. The recent decision of the Illinois Supreme Court in GTE Automatic Electric, Inc. v. Allphin ${ }^{1}$ is an exception, however. It construes a statute substantially identical to one in force in over half the states, ${ }^{2}$ addressing a question of first impression ${ }^{3}$ and advancing a solution that raises a host of statutory and constitutional problems. Because other state courts are likely to be confronting the issues raised by $G T E^{4}$ and because the constitutional problems involved are unlikely to be resolved definitively in the near future, ${ }^{5}$ the Illinois court's opinion merits critical examination.

Part I of this article examines the structure and underlying policy of the Uniform Division of Income for Tax Purposes Act's provisions relating to the apportionment of income arising from economic activity conducted across state lines. In particular, it considers the Act's "throwback" rule, which reapportions income ordinarily apportioned to a state in which it is not taxable to one in which it is. Part II explores in detail the Illinois court's resolution of the problem raised by GTE, namely, how to assign sales of tangi-

$\dagger$ Assistant Professor of Law, University of Chicago, on leave of absence 1978-79; the author is currently teaching at the University of Georgia School of Law.

168 Ill. 2d 326, 369 N.E.2d 841 (1977).

2 Illinois Income Tax Act, \$\& 301-307, Ir.. Rev. Stat. ch, 120, §§ 3-301 to 3-307 (1973). See State \& Loc. Taxes (All States Unit) (P.H) I 1046, col. A., nn.6 \& 9 (1977). See also text and notes at notes $12-14$ infra.

${ }^{3} 68$ IIl. $2 \mathrm{~d}$ at 335,369 N.E.2d at 845.

- A number of states have adopted regulations promulgated by the Multistate Tax Commission, see note 91 infra, that arguably require the same result reached by the Illinois Supreme Court. See, e.g., CaL. Corp. Inc. TAX REg. 25135(a)(7), reprinted in State \& Loc. TAXEs (Cal.) (P-H) I 11,538-C.30 (1973); IDaho Inc. TAX REg. 27.IV.16.(a)(7), reprinted in State \& Loc. Taxes (Idaho) (P-H) I 11,677-F.30 (1974); Neb. Inc. \& Franch. Tax Reg. 2438(7), reprinted in STATE \& Loc. TAXEs (Neb.) (P-H) I 11,674-R.30 (1975).

s GTE did not appeal the Illinois Supreme Court's decision to the United States Supreme Court. 
ble personal property, which are used as a basis for apportioning income, when such sales are effected by a taxpayer whose income is taxable in neither the state of the sales' origin nor that of their destination. Part III suggests an alternative resolution of the controversy that serves the relevant statutory and constitutional interests more fully than the Illinois court's opinion, while ensuring that all of a taxpayer's income is taxable by the states.

\section{UDITPA AND THE "THROWBACK" RULE}

\section{A. Allocation and Apportionment of Income}

1. The Principle of 100 Percent Taxability. The Uniform Division of Income for Tax Purposes Act ("UDITPA") was approved and recommended for adoption in 1957 by the National Conference of Commissioners on Uniform State Laws and by the American Bar Association. ${ }^{8}$ The Act addressed the problem of how to divide the income of a multistate business for tax purposes among those states possessing power to tax some portion of that income. ${ }^{7}$ In place of the "exceedingly diverse" methods developed by the states over the years, ${ }^{8}$ UDITPA proposed uniform principles of allocation and apportionment' of a multistate firm's income designed to simplify the task of tax collection and reporting and to ensure that 100 percent of a multistate firm's income-neither more nor less-is taxable by the states. ${ }^{10} \mathrm{As}$ of late 1978 , out of forty-six states levying corporate taxes on or measured by net income, ${ }^{11}$ twenty-seven states and the District of Columbia had in substance adopted the Act. ${ }^{12}$

- 7A U.L.A. 91 (1978). The Uniform Division of Income for Tax Purposes Act [hereinafter cited without cross-reference as UDITPA] appears at id., 93-108. It is also reproduced as article IV of the Multistate Tax Compact in STATE \& Loc. TAXes (All States Unit) (P-H) I 6315-6332 (1975).

- See generally Lynn, Formula Apportionment of Corporate Income for State Tax Purposes: Natura Non Facit Saltum, 18 Oно ST. L.J. 84 (1957); Lynn, The Uniform Division of Income for Tax Purposes Act, 19 Oнnо St. L.J. 41 (1958); Pierce, The Uniform Division of Income for State Tax Purposes, 35 Taxes 747 (1957).

- Lynn, Formula Apportionment of Corporate Income for State Tax Purposes: Natura Non Facit Saltum, supra note 7, at 87.

"The terms "allocation" and "apportionment" are often used interchangeably in statutes and decisions dealing with the division of income (or other tax measures) among the states. Increasingly, however, the term "allocation" is used to refer to the attribution of a particular type of income, receipt, property, or the like to a designated state whereas "apportionment" refers to the division of the tax base by formula. This is the terminology employed by UDITPA and by this article.

10 Pierce, supra note 7, at 748.

"STate \& Loc. Taxpes (All States Unit) (P-H) II 1046 (1977).

12 Id. at col. A, nn.6 \& 9 (1977). A number had done so by subscribing to the Multistate Tax Compact, which incorporates UDITPA. See note 91 infra. 
It is important at the outset to understand that UDITPA does not attempt to ensure that 100 percent of a multistate firm's income is actually taxed by the states; it seeks only to ensure that 100 percent of such income is taxable by them. Thus, the application of the Act is triggered when the taxpayer has income from business activity that is taxable in more than one state, whether or not it is actually taxed in more than one state. ${ }^{13}$ An enterprise is "taxable" in a state if (1) it is "subject to a net income tax, a franchise tax measured by net income, a franchise tax for the privilege of doing business, or a corporate stock tax, or (2) that state has jurisdiction to subject the taxpayer to a net income tax regardless of whether, in fact, the state does or does not." 14 In other words, income may be attributed to states that do not in fact tax it, as long as they have the power to impose a net income tax on the taxpayer.

The decision to attribute income to states where it is taxable but not actually taxed has been defended by one of UDITPA's. draftsmen on the ground that

[i]n states not having income taxes or taxes measured by net income, other types of franchise taxes are usually imposed. Income is justifiably attributable to these states since these other taxes substitute for the income tax, and it must be recognized that these other states may change their tax structures at any time..$^{15}$

Beyond that, it might have been thought that any rule not predicated on the assumption that all states with power to impose an income tax had done so would subject interstate business to a risk of multiple taxation forbidden by the commerce clause. ${ }^{16}$

On the other hand, UDITPA goes to considerable lengths in an apparent effort to ensure that all of a multistate firm's income is taxable somewhere: for example, the Act's "throwback" rule, which is the focus of this article, is a device for apportioning income to a state that has the power to tax it when UDITPA's normal attribution rules would apportion such income to a state that does not. ${ }^{17}$ This may seem inconsistent with UDITPA's indifference to whether

13 UDITPA \& 2. Income derived from "activity as a financial organization or public utility or the rendering of purely personal services by an individual" is excluded from the scope of the Act. Id.

"UDITPA \& 3.

is Pierce, supra note 7, at 749.

11 U.S. ConsT. art. I, 88 , cl. 3. The multiple taxation doctrine, and the question of its application to taxpayers potentially exposed but not actually subjected to multiple tax burdens, are considered at text at notes 159-177 infra.

${ }^{17}$ See text and notes at notes 39-41 infra. 
income is actually taxed, but there is a principled distinction between attempting to ensure that 100 percent of a firm's income is available for taxation by the states and attempting to ensure that it is actually taxed by them. UDITPA generally attempts to achieve the first objective and furthers the second only to the extent that efforts to accomplish the former necessarily promote the latter.

2. The Sales Factor. The Act's basic rules for allocation and apportionment require the segregation of the taxpayer's income into "business income" ("income arising from transactions and activity in the regular course of the taxpayer's trade or business") ${ }^{18}$ and "non-business income" ("all income other than business income"). ${ }^{19}$ Each item of non-business income is generally allocated to the particular state or states designated by UDITPA..$^{20}$ Business income, however, is apportioned by a formula that, in substance, apportions to the taxing state a percentage of the taxpayer's income equal to the average of three ratios: ${ }^{21}$ the ratio of the taxpayer's in-state property to its total property, ${ }^{22}$ of its in-state payroll to its total payroll, ${ }^{23}$ and of its in-state sales receipts to its total sales receipts. ${ }^{24}$ The formula weighs the three factors-property, payroll, and sales-equally, no matter how important or unimportant one of them may be in a firm's operations. ${ }^{25}$

With regard to the apportionment of business income, neither

18 UDITPA \& 1(a).

1 Id. $\S 1(\mathrm{e})$. This task may well be a difficult one. See J. Hedlerstain \& W. Hellerstain, State and Local Taxation: Cases and Matkpials 490-504 and sources cited therein (4th ed. 1978) [hereinafter cited as HELLERSTEIN \& HELLRRSTEIN].

2 UDITPA \&\& 4-8. UDITPA specifically refers only to the allocation of "[r]ents and royalties from real or tangible personal property, capital gains, interest, dividends, or patent or copyright royalties, to the extent that they constitute non-business income." Id. § 4. The Act may thus have failed to provide for either the allocation or apportionment of non-business income not described as allocable under section 4, as, for example, income from services held not to constitute business income. See Hellerstein \& HeLlerstgin, supra note 19, at 469. But see UDITPA $\$ 18$, set out in the text at note 68 infra and text at notes 118-119 infra.

2) UDITPA $\S \S 9-17$.

22 Id. $\$ 10$. For purposes of determining this ratio, property is defined as "the average value of the real and tangible property owned or rented and used" by the taxpayer. Id. Sections 11 and 12 of UDITPA provide for methods of valuing the property and for determining its average value.

2 Id. $\S 13$. Section 14 of UDITPA provides guidelines for determining the state in which compensation is deemed to be paid.

24 Id. \$ 15. Sections 16 and 17 of UDITPA provide guidelines for determining the state to which receipts should be assigned.

${ }^{25}$ The Illinois statute, which generally tracks UDITPA, see note 74 infra, provides, however, that when the denominator of any factor is zero, it drops out of the formula altogether. Illinois Income Tax Act, ILL. REv. STAT. ch. 120 \& 3-304 (1973). This was characterized as "a comparatively significant change" from UDITPA in the Technical Explanation of the Illinois Income Tax Act. State \& Loc. TAxEs (IIl.) (P-H) II 10,953.40 (1973). 
the property nor the payroll factor has been the subject of extensive controversy, although questions have occasionally arisen concerning their appropriate definition and interpretation..$^{26}$ It is the sales factor that has generated the most conflict in this context. ${ }^{27}$ The debate over the sales factor has focused on two significant problems: determining the jurisdiction to which a taxpayer's sales or receipts should be assigned, and, in cases in which the taxpayer is not taxable in that jurisdiction, determining whether, and in what manner, to modify the initial assignment of sales or receipts. ${ }^{28}$;

In approaching these problems, UDITPA distinguishes between receipts from sales of tangible personal property and other receipts, such as those from sales of services. With respect to the latter category, UDITPA attributes receipts to the state in which "the incomeproducing activity is performed" or, if it is performed in more than one state, to the state in which "a greater proportion of the incomeproducing activity is performed ... . based on costs of performance." 29 This rule may be questioned on the ground that its all-ornothing approach for assigning receipts for services is inequitable and that it would be fairer to attribute such receipts on a time or cost basis so that when substantial work is done in more than one state, each state would benefit. ${ }^{30}$ The provision may also be faulted for dealing inadequately with receipts other than those from services, although the Act's draftsmen recognized this problem and deliberately left its resolution to be worked out through the general relief provision of UDITPA. ${ }^{31}$ Although questions may thus be raised concerning UDITPA's rule for assigning these types of receipts, the rule itself creates no pressure for modification of the initial assignment, since the state to which the receipts are assignedthe state in which the income-producing activity (or most of it) is performed-is virtually certain to be one in which the taxpayer is taxable.

Receipts from sales of tangible personal property, however, give rise to a more complex controversy involving not only the choice of the normal rule of attribution for purposes of the sales factor, but

27 See Hellerstrain \& HrLLerstkan, supra note 19, at 455-58, and sources cited therein.

2 See id. supra note 19, at 458-75; Cox, The NCCUSL Uniform Apportionment Formula, 42 Taxes 530, 533 (1964); Lynn, The Uniform Division of Income for Tax Purposes Act, supra note 7 , at $49-51$.

23 See Hellezstzin \& Hellerstein, supra note 19, at 467-75.

2 UDITPA \& 17.

${ }^{30}$ Keesling \& Warren, California's Uniform Division of Income for Tax Purposes Act (pt. II), 15 U.C.L.A. L. Rzv. 655, 674 (1968); Wilkie, Uniform Division of Income for Tax Purposes, 37 TAXES 65, 73 (1959).

31 Pierce, supra note 7, at 780-81. The relief provisions of Section 18 of UDITPA are set out at note 68 infra and discussed at notes 112-119 infra. 
also the question whether the selected rule should be modified in certain cases. Four different rules of attribution have been developed for attributing receipts from sales of tangible personal property: (1) the sales destination test, which attributes sales receipts to the state in which goods are shipped or delivered to the customer; (2) the sales origin test, which attributes sales receipts to the state of the factory, warehouse, or office from which the goods are shipped; (3) the sales office negotiation test, which attributes sales receipts to the state of the sales office at which the sale was principally negotiated; and (4) the sales activity test, which attributes sales receipts to the state in which the sales employees principally conduct their selling activities. ${ }^{32}$

Section 16 of UDITPA adopted a destination test as the basic rule of attribution for sales of tangible personal property:

$\S 16$ [Situs of Sales of Tangible Personal Property] Sales of tangible personal property are in this state if:

(a) the property is delivered or shipped to a purchaser, other than the United States government, within this state regardless of the f.o.b. point or other conditions of the sale; or

(b) the property is shipped from an office, store, warehouse, factory, or other place of storage in this state and (1) the purchaser is the United States government or (2) the taxpayer is not taxable in the state of the purchaser. ${ }^{33}$

In adopting a destination test for sales of tangible personal property, the UDITPA draftsmen were influenced in part by administrative considerations: to take into account, in addition, the state of origin and the state of negotiation, as the Council of State Governments had suggested, threatened to complicate both tax administration and compliance. ${ }^{34}$ More important, however, the UDITPA draftsmen sought to give recognition to the contribution of the market states to the production of a firm's income.$^{35}$ While acknowledging that an origin test would have been the preferred choice of the manufacturing states, the National Conference of Commissioners on Uniform State Laws "was of the opinion that [a sales factor with an origin test] would merely duplicate the property and payroll

I See Hellarstein \& Hellerstzin, supra note 19, at 459.

3 UDITPA $\& 16$. The heading was not part of the original Act; it was supplied by the editor of the Uniform Laws Annotated. See 7A U.L.A. 91 (1978).

अ Lynn, Formula Apportionment of Corporate Income for State Tax Purposes: Natura Non Facit Saltum, supra note 7 , at 98.

s Pierce, supra note 7 , at 780. 
factors which emphasize the activity of the manufacturing state." 30 Although, as one commentator had written earlier, "[s]uch theory doesn't go far in reconciling basic clashes in economic interests or in palliating the impact of potential revenue loss," 37 the adoption of the destination test is now so widespread as to render academic any question of its acceptability. ${ }^{38}$

The adoption of a destination test as the basic rule of attribution for sales of tangible personal property, however, can give rise to the second problem adverted to above-determining whether to modify the initial assignment of sales-by creating a situation in which the taxpayer is not taxable in the jurisdiction to which its receipts have been assigned under the normal rule of attribution. Both constitutional and federal statutory limitations restrict the power of the destination state to impose a net income tax on an interstate vendor whose contacts with the state are confined to solicitation through instrumentalities of interstate commerce and to other specified activities. Although the constitutional limitations in this context may be minimal, they cannot be ignored..$^{38}$ Of greater significance, however, is the federal statutory limitation imposed by Public Law Number $86-272,{ }^{40}$ which prevents a state from imposing a tax measured by net income on foreign corporations deriving income from interstate commerce in the state if the corporation's only activities in the state amount to solicitation of orders for sales of tangible personal property or the effecting of such sales through independent contractors. ${ }^{41}$

${ }^{3}$ Id. See also Cox, supra note 27, at 533; Lynn, Formula Apportionment of Corporate Income for State Tax Purposes: Natura Non Facit Saltum, supra note 7, at 98.

${ }^{7}$ Lynn, Formula Apportionment of Corporate Income for State Tax Purposes: Natura Non Facit Saltum, supra note 7 , at 98.

3s The destination test of attribution of receipts from sales of tangible personal property is now used in whole or in part in $\mathbf{4 2}$ of the $\mathbf{4 5}$ jurisdictions (44 states and the District of Columbia) that employ a sales or receipts factor in their apportionment formulas. STATE \& Loc. TAxes (All States Unit) (P-H) If 1047 (1977).

39 Although the scope of National Bellas Hess, Inc. v. Department of Revenue, 386 U.S. 753 (1967), which held that the commerce and due process clauses forbade a state from imposing a use tax collection duty on an interstate vendor whose only contact with the state was through the mail or common carriers, has been narrowed by National Geographic Soc'y v. State Bd. of Equalization, 430 U.S. 551 (1977), and, perhaps, by Standard Pressed Steel Co. v. Department of Revenue, 419 U.S. 560 (1975), some contact beyond a mail-order sale is probably still necessary before a state can constitutionally tax the income of an out-of-state firm regardless of the applicability of Pub. L. No. 86-272. See note 40 infra.

- Act of Sept. 14, 1959, Pub. L. No. 86-272, \& 101, 73 Stat. 555 (codified at 15 U.S.C. $\S$ 381 (1976)).

1 Public Law No. 86-272 was enacted in response to the Supreme Court's decision in Northwestern States Portland Cement Co. v. Minnesota, 358 U.S. 450 (1959)(together with Williams $v$. Stockham Valves \& Fittings, Inc.), which held that a state could impose a nondiscriminatory, fairly apportioned net income tax on a foreign corporation engaged in 


\section{B. Reassignment of Sales: The Throwback Rule}

When constitutional or statutory strictures preclude the destination state from imposing a net income tax on an interstate vendor, application of the sales destination test will necessarily shield some of the taxpayer's income from taxation. This result-which is a "problem," of course, only for those who believe that all of a taxpayer's income should be taxable-has spawned two countermeasures: (1) the "throwback" rule, which reassigns (or "throws back") to a state in which the taxpayer is taxable the receipts that would normally be assigned to a jurisdiction in which the taxpayer is not taxable, and (2) the "throwout" rule, which eliminates (or "throws out") from both the numerator and the denominator of the sales factor the receipts that would ordinarily be assigned to a jurisdiction in which the taxpayer is not taxable. The throwback rule increases the apportionable income of the state to which the receipts have been reassigned without affecting the apportionable income of other states that have the power to tax the taxpayer. Under the throwout rule, the receipts attributed to the other states remain the same, but since the common denominator is now smaller, each state's fractional share of the taxpayer's apportionable income is proportionally increased.

UDITPA adopted the throwback rule for two different situations: when the purchaser is the United States government and when the taxpayer is not taxable in the state of the purchaser. ${ }^{42}$ Although the appropriateness of the throwback rule for reassigning receipts from government purchases may be questioned, ${ }^{43}$ the greater source of controversy is UDITPA's application of the throwback rule to receipts from tangible personal property when the taxpayer is not taxable in the state of the purchaser.

exclusively interstate commerce in the state. See W. Hellerstein, State Taxation of Interstate Business and the Supreme Court, 1974 Term: Standard Pressed Steel and Colonial Pipeline, 62 VA. L. REv. 149, 151-53 \& n.17 (1976). Cases interpreting this statute are discussed in HrLLERSTEIN \& Hellerstein, supra note 19, at 339-58 and sources cited therein.

12 UDITPA \& 16. See text at note 33 supra.

4 The draftsmen's justification for the use of the throwback rule in connection with sales to the United States government was that such sales "are not necessarily attributable to a market existing in the state to which the goods are originally shipped." Commissioner's Note to UDITPA \& 16, 7A U.L.A. 105 (1970). This appears to be fair, since the contribution of the market state to the generation of income is the basis for using a destination test in the first place. But the question may be raised whether reassigning such receipts to the state of origin is any more acceptable than assigning them to the state of destination. A throwout rule in these circumstances would appear to be more satisfactory since it would avoid a disproportionate attribution of income from defense and other government contracts to the manufacturing states. See HeLlERstzin \& HeLLERSTEn, supra note 19, at 466-67. 
The core of the controversy over UDITPA's application of the throwback rule in the latter context lies in fundamental considerations of tax policy and constitutional law. The rationale behind the rule is plain enough: on the assumption that all of a firm's apportionable income ought to be apportioned to some state with the constitutional power to tax it, the rule is intended to prevent the apportionment of income to states without such power. Taxpayers are thus denied the opportunity of relying on the normal sales attribution rules to produce a tax-free haven for a portion of their income. ${ }^{44}$ Policy-based arguments against the throwback rule take two basic forms. First, some oppose 100 percent taxability as a policy goal: ${ }^{45}$ much of the opposition to the throwback rule has understandably emanated from spokesmen for multistate business who "can hardly be expected to rejoice at a provision which purportedly attempts to insure that all sales will be included in the numerator of the sales factor of either the state of destination or the state of origin of the goods sold." ${ }^{46}$ Second, the operation of the rule has been attacked on the grounds that it illogically determines how much income is attributable to one state by looking to activities in another, ${ }^{47}$ that it encourages taxpayers to adopt uneconomic routing procedures in order to minimize their taxes, ${ }^{48}$ and that it creates administrative and compliance problems. ${ }^{48}$

The throwback rule has also been attacked on constitutional grounds. In Covington Fabrics Corp. v. South Carolina Tax Commission, ${ }^{50}$ the application of a throwback rule substantially the

4 See, e.g., Corrigan, Interstate Corporate Income Taxation-Recent Revolutions and a Modern Response, 29 VAND. L. REv. 423, 430-31 (1976). If the sales of a mail-order seller were assigned to the states of its purchasers in accordance with UDITPA's destination test, but the seller was not taxable in one or more of these states, see text and notes at notes 39-41 supra, the result would be to apportion part of the seller's income to states in which it could not be taxed, thereby assuring that the seller would be taxable on less than all of its income and undermining one of the basic goals of UDITPA. To avoid this possibility, UDITPA provides that under these circumstances the sales are thrown back to the state of origin, thus making certain-or so it was thought (see Part II infra) - that all of a taxpayer's income would be taxable.

is See, e.g., Lynn, The Uniform Division of Income for Tax Purposes Act Re-Examined, 46 VA. L. REv. 1257, 1266 (1960).

" Lynn, The Uniform Division of Income for Tax Purposes Act, supra note 7, at 50-51 (footnote omitted).

${ }^{17}$ State Taxation of Interstate Commerce: Hearings Before the Subcomm. on State Taxation of Interstate Commerce of the Senate Comm. on Finance, 93d Cong., 1st Sess. 275 (1973) (industry statement on proposed interstate tax legislation).

ts Id.

- Id. See also Lynn, Formula Apportionment of Corporate Income for State Tax Purposes: Natura Non Facit Saltum, supra note 7, at 98; Wilkie, supra note 30, at 73.

${ }^{30} 264$ S.C. 59, 212 S.E.2d 574, appeal dismissed, 423 U.S. 805 (1975). 
same as UDITPA's $\mathrm{s}^{51}$ was challenged under the commerce and due process clauses. The taxpayer, a New York corporation with its head office in New York City, acquired fabric in unfinished form and had it processed by independent contractors in several states. Most of the finished saleable goods were sent to a South Carolina warehouse. The goods were then shipped to customers throughout the United States who had been solicited by agents working out of sales offices in New York, Illinois, and California. In apportioning its income to South Carolina under the state's three-factor formula (property, payroll, and sales) the taxpayer, pursuant to the destination test, assigned one percent of its sales to South Carolina-namely, those sales delivered to South Carolina customers. The state tax commission, invoking the throwback rule, included in the numerator of the sales factor receipts from all sales shipped from South Carolina into states in which the taxpayer was not taxable. As a result, nearly 80 percent of the taxpayer's sales were assigned to South Carolina. ${ }^{52}$

Without specifically addressing any of the issues peculiar to the operation of the throwback rule, the South Carolina Supreme Court sustained the apportionment. Reciting the shibboleths that "[o]ne who attacks a formula of apportionment carries a distinct burden of showing by 'clear and cogent' evidence that it results in extraterritorial values being taxed"s3 and that in matters of apportionment " 'rough approximation rather than precision' is sufficient," 54 the court pointed out that the record revealed that, even after reassignment of sales to South Carolina, the taxpayer was taxable in only three states and on only 83 percent of its income. ${ }^{55}$ The court refused to find that the apportionment of 55 percent of appellant's income to South Carolina - the portion attributed after averaging in the $\mathbf{7 0}$ percent property factor and 17 percent payroll factor-was "unreasonable and unrelated to business done in [the] state."

A more careful and illuminating opinion sustaining the constitutionality of the throwback rule was issued by the Supreme Court

\footnotetext{
${ }^{31}$ Income Tax Act of 1926, S.C. Code $\$ 12-7-1170$ (1977) (formerly S.C. CoDE $\$$ 65-279.6), quoted in Covington Fabrics, 264 S.C. at 64, 212 S.E.2d at 576.

52 Since the property and payroll factors were 70 percent and 17 percent respectively, and the final apportionment percentage was 55.5 percent, see text at note 56 infra, the sales factor must have come to 79.5 percent.

53 Butler Bros. v. McColgan, 315 U.S. 501, 507 (1942), quoted in Covington Fabrics, 264 S.C. at 66, 212 S.E.2d at 577.

st International Harvester Co. v. Evatt, 329 U.S. 416, 422 (1947), quoted in Covington Fabrics, 264 S.C. at 67, 212 S.E.2d at 578 (citations omitted).

ss 264 S.C. at 68,212 S.E.2d at 578.

se Id. at $68-69,212$ S.E.2d at 578-79.
} 
of New Hampshire in Scott \& Williams, Inc. v. Board of Taxation. ${ }^{57}$ The taxpayer, a manufacturer of knitting machines, had its principal business office and sole manufacturing plant in New Hampshire, a sales office in New York, a warehouse and sales office in North Carolina, and a subsidiary in Belgium. It carried on regular sales activity in several states and also made sales to purchasers in other states and foreign countries. The taxpayer objected to the assignment to New Hampshire, under the throwback rule, of sales shipped from New Hampshire to states where it was not taxable, alleging that the application of the rule violated the commerce, due process, and equal protection clauses.

The court observed that the apportionment provisions were designed to measure the proportion of the taxpayer's income derived from activities conducted in New Hampshire and that the sales factor was employed with a destination test to reflect the contribution made by the market state to the production of such income. ${ }^{58}$ The court then declared:

However, if a state where products are delivered has not provided benefits sufficient to entitle it to tax any portion of the business' income, then it is proper to attribute the production of income from those sales entirely to the state or states which have provided "protection[,] opportunities and benefits" to the business throughout the manufacturing process up to the point of shipment to the purchaser. . . A Allocation of such sales to New Hampshire, the state of shipment, under the "throwback rule" therefore does not constitute taxation of extraterritorial values. Rather, it is an allocation of those sales to the state most entitled to levy a tax in return for the opportunities, protections and benefits which it has afforded the taxpayer. The operation of the "throwback rule" may not result in a mathematically precise measure of the proportion of plaintiff's business activities conducted in New Hampshire. However, if the apportionment formula provides reasonable apportionment of plaintiff's income according to its sources or to the "social costs" generated by plaintiff"s business activities, this lack of precision will not render it invalid.

The court's analysis sustaining the critical principle underlying

37372 A.2d 1305 (N.H. 1977). Although New Hampshire has not formally adopted UDITPA, the apportionment provisions of its business income tax are virtually identical to those contained in UDITPA. N.H. REv. Stat. ANn. § 77-A:3 (III) (Supp. 1977).

ss 372 A.2d at 1308 .

3s Id. at 1308-09. 
the throwback rule may be questioned from the standpoints of logic and policy. One may argue that it is illogical to posit a method for apportioning income based on the assumption that the market state contributes to its production and then to abandon that assumption as a consequence of some extraneous factor such as the taxpayer's invulnerability to taxation in the market state. The court's analysis rests on the assumption that there is a correlation between the factors that render a taxpayer taxable in a state and the factors that contribute to its production of income there. But whether a taxpayer has the requisite contacts with a state to render it taxable there would in fact seem to have no necessary relation to whether the existence of a market in that state contributed to the production of the taxpayer's income.

In terms of the underlying basis for apportioning income, it is therefore a nonsequitur to suggest, as the court does, that "if" the taxpayer has no taxable nexus with the market state, "then" it is "proper" to attribute income from sales into that state to states with the requisite nexus. It is only "proper" to do so because of the consideration, which is logically distinct from the question of where income is earned, that multistate businesses should be taxable on 100 percent of their income. Apportionment principles designed to achieve that objective may be inconsistent with a theoretically sound approach to the question of where income is earned. To tamper with basic apportionment doctrine in this manner, it may be contended, is unsound policy.

Nevertheless, the court's sanction of the throwback rule rests on solid constitutional ground. Since the states enjoy broad leeway under the Constitution in their choice of formulas for apportioning the income of a multistate business, ${ }^{60}$ and since there is no doubt that the states possess the constitutional power to employ either an origin, destination, or other reasonable test for assigning sales to the numerator of the sales factor, ${ }^{61}$ the only question is whether the combined use of the origin and destination tests in connection with the throwback rule violates some constitutional principle in this area.

Unless the throwback rule threatens to saddle a multistate business with some burden it does not already bear under existing criteria governing state apportionment formulas, it would seem that the use of such a formula would be sustained as a reasonable exercise of the state's tax power. Since the rule applies only in those

" Moorman Mfg. Co. v. Bair, 437 U.S. 267, 273 (1978).

"Id. at 278 \& n.13; International Harvester Co. v. Evatt, 329 U.S. 416, 422-23 (1947). 
situations in which the taxpayer is not taxable in the jurisdiction to which the sales would otherwise be assigned, and since the rule limits the throwback to a single state with jurisdiction to taxnamely, the state of origin-the rule would not appear to impose any additional burden of constitutional magnitude on the multistate business. ${ }^{62}$

In response to the taxpayer's claim that the throwback rule was unconstitutionally vague because it depended on the various tax laws of other states, the New Hampshire court in Scott \& Williams emphasized that the application of the rule turned on whether the taxpayer was potentially taxable in the state of the purchaser, not on whether it was in fact taxed there. ${ }^{63}$ Resolution of this issue depended, of course, on a single body of federal constitutional and statutory law. The court likewise dismissed the claim that the administrative burden imposed on the taxpayer by the throwback rule rendered it unconstitutional. ${ }^{\text {4 }}$ With regard to the contention that the application of the throwback rule to the taxpayer violated the equal protection clause by imposing unequal tax burdens on corporations having identical contacts with the state, the court observed:

This argument is based on a false premise. If two corporations with identical total business activity are taxed differently by virtue of the "throwback rule," this is because they do not have identical business contacts with New Hampshire. The amount of a corporation's business activity within New Hampshire will be determined in inverse proportion to the amount of that corporation's business activity in other states. If a corporation conducts sufficient business activity in other states to render it taxable in those states, the amount of its business activity in New Hampshire will necessarily be less in comparison to a corporation whose business activity in other states is not of a sufficient amount to render it taxable in some or all of those

i2 Perhaps one could contend that the broad latitude the states have been accorded in their choice and implementation of apportionment formulas, which imposes a heavy burden on the taxpayer to prove unfair apportionment and holds the states only to the relaxed standard of "rough approximation," ought to give rise to a countervailing constitutional principle that forbids the states to fine-tune their formulas to close incidental jurisdictional gaps that may be created by the adoption of a particular formula. The claim, in substance, is that the lacunae that may be created by the states' choice of a particular method for apportioning income provide at least some measure of protection to the multistate business confronted with the inconsistency and overlap in state apportionment formulas that are tolerable under prevailing constitutional standards. But this does not strike me as a winning argument.

a 372 A.2d at 1309-11. See also text at notes 13-17 supra.

4 $372 \mathrm{~A} .2 \mathrm{~d}$ at 1310. 
states. As we apply a uniform standard to determine taxability in other states, all corporations having identical out-of-state contacts will be treated in the same manner in New Hampshire under the "throwback rule." Plaintiff's equal protection argument must therefore fail."s

Both the court's assumption that there exists an inverse relationship between business activity in the destination state and the shipping state and its conclusion that all firms having identical outof-state contacts will be treated in the same manner in the shipping state under the throwback rule are open to question. The lack of business activity in one destination state may be compensated by increased activity in a state other than the shipping state in one case, and by increased activity in the shipping state in another, yet the tax consequences will be the same if both are not taxable in the destination state. Nevertheless, given the wide latitude enjoyed by the states under the equal protection clause in making classifications for tax purposes, ${ }^{68}$ it is highly unlikely that this "minor inequality"'67 would induce the Supreme Court to declare the throwback rule unconstitutional.

Finally, with respect to the general structure of UDITPA, it is important to note that when any of the Act's provisions, including the throwback rule, produces a result that does not fairly reflect the extent of the taxpayer's business activity in the taxing state, the Act's relief provision may come into play:

$\S 18$. [Apportionment by Tax Administrator]

If the allocation and apportionment provisions of this Act do not fairly represent the extent of the taxpayer's business activity in this state, the taxpayer may petition for or the [tax administrator] may require, in respect to all or any part of the taxpayer's business activity, if reasonable:

(a) separate accounting;

(b) the exclusion of any one or more of the factors;

w Id. While sustaining the constitutionality of the throwback rule, the court remanded for a determination of whether the taxpayer was taxable in the jurisdictions in which it made sales, id. at 1311, which would, of course, preclude application of the rule. In New Jersey Mach. of N.H., Inc. v. New Hampshire Dept. of Revenue Administration, 372 A.2d 604 (N.H. 1977), a case decided on the same day as Scott \& Williams, the court rejected an identical attack on the constitutionality of the throwback rule.

" See, e.g., Lehnhausen v. Lake Shore Auto Parts Co., 410 U.S. 356 (1973).

i As the Court stated in Salomon v. State Tax Comm'n, 278 U.S. 484, 491-92 (1929): "To all such objections it may be answered that minor inequalities and hardships are incidents of every system of taxation and do not render the legislation obnoxious to the Federal Constitution." 
(c) the inclusion of one or more additional factors which will fairly represent the taxpayer's business activity in this state; or

(d) the employment of any other method to effectuate an equitable allocation and apportionment of the taxpayer's income. ${ }^{88}$

The precise purpose and scope of this section were of central importance to the Illinois Supreme Court's opinion in GTE. ${ }^{89}$

\section{GTE Automatic Electric, INC. v. Allphin}

Despite the conflict generated by UDITPA's throwback rule, neither its basic operation nor its constitutionality were challenged by GTE Automatic Electric when it filed suit seeking to enjoin application of the rule as interpreted by the Illinois Department of Revenue. According to the allegations of its complaint, GTE dutifully included in the numerator of its sales factor all sales of tangible personal property "shipped from plaintiff"s Illinois inventory to purchasers in states in which it is not taxable." 70 The dispute in the case centered on sales involving a critical additional fact: not only was the property sold shipped to states in which the taxpayer was not taxable, it was also shipped from states in which the taxpayer was not taxable. ${ }^{71}$ The balance of this article considers the appropriate treatment of receipts from such sales in light of the Illinois Supreme Court's opinion in GTE and the language and purpose of UDITPA.

\section{A. The Factual and Procedural Background ${ }^{72}$}

GTE Automatic Electric, Inc., is a Delaware corporation with

"s UDITPA \& 18.

6 68 Ill. 2d 326, 369 N.E.2d 841 (1977).

7 Record at C7, GTE Automatic Elec. Inc. v. Allphin, 68 Ill. 2d 326, 369 N.E.2d 841 (1977).

"A second class of sales was also at issue: sales of tangible personal property shipped by the taxpayer's supplier from the supplier's inventory in Illinois to purchasers in states in which the taxpayer was not taxable. Because these sales fall squarely within the language of UDITPA's throwback rule and because their inclusion in the numerator of the taxpayer's sales factor raises no substantial constitutional issue, they will not be considered further here.

72 Because the appellate opinions in the case are virtually barren of facts, the description of facts in the text is drawn principally from the record. Many of the particulars are derived from the affidavits of A.R. Reeland, GTE's Tax Manager, and John L. Roupas, a Revenue Auditor for the Illinois Department of Revenue, submitted in support and opposition, respectively, to GTE's Motion for Summary Judgment in the Cook County Circuit Court. See Record, supra note 70, at C57-C61, C75-C82. I have attempted, except as otherwise indicated, to refer only to facts that were either admitted by the pleadings or appear uncontradicted in the record. 
its principal place of business in Northlake, Tlinois. GTE is engaged primarily in the manufacture and sale of communications equipment. ${ }^{73}$ During the tax years in question, GTE derived income from taxable business activity carried on in Illinois and other states.

In filing its income tax returns for 1969 through 1971 under the Illinois income tax statute, which, insofar as here relevant, is identical to UDITPA, ${ }^{74}$ GTE reported its sales factor as follows. Sales of tangible personal property (1) delivered or shipped to purchasers in Illinois and (2) shipped from GTE's Illinois inventory to the United States government or to purchasers in states where GTE was not taxable were deemed to be sales "within Illinois" and were included in the numerator of the sales factor. All sales of tangible personal property, wherever made, were deemed to be the "total [sales] everywhere" and were included in the denominator of the sales factor. ${ }^{75}$ The denominator, but not the numerator, included receipts from sales of tangible personal property shipped by GTE's supplier from states in which GTE was not taxable to states in which GTE likewise was not taxable..$^{76}$

Upon audit, the Illinois Department of Revenue took the position that receipts from sales of property shipped both from and to states in which GTE was not taxable should be included in the numerator of the Illinois sales factor. It relied on a regulation providing:

A person using the sales factor under the Illinois Income Tax Act shall compute the numerator and denominator of such

73 [1977] General Tet. \& Elgc. Corp. Ann. Rep. 7, 30; Moody's Public Utilities MANuAL 781 (1977). GTE Automatic Electric is a wholly-owned subsidiary of General Telephone \& Electronics Corp. Id.

"See ILL. Rgv. Stat. ch. 120, \& 3-304 (1977). The current statute reflects the law in effect during 1969-71. Illinois became a member of the Multistate Tax Compact in 1967 and thereby enacted the provisions of UDITPA. IL.. Rsv. STAT. ch. 120, 8871 (1973). In enacting the Illinois Income Tax Act of 1969, the legislature adopted separate allocation and apportionment provisions substantially similar, but in some instances not identical, to those of UDITPA. Compare Iul. Rev. Stat. ch. 120, 88 3-301 to 3-307 (1977) with UDITPA. See generally Illinois Income Tax Act - Technical Explanation, reprinted in STATE \& Loc. TAXrs (IIl.) (P-H) If 10,953 (1973). See also note 25 supra. Both the Compact (and thus UDITPA) and the analogous statutory provisions were in effect in Illinois during the tax years in question, although Illinois subsequently withdrew from the Compact in 1975 (thus repealing UDITPA, but not its statutory analogue). Act of June 15, 1967, \& 1, 1967 Ill. Laws 661 (repealed 1975). There was some disagreement between the taxpayer and the Director over whether the taxpayer had elected to apportion its income pursuant to the Compact or the Illinois Act. See Brief for Appellant at 17, GTE, 68 Ill. 2d 326, 369 N.E.2d 841 (1977); Brief for Appellee at 70, id. The dispute, however, did not concern the applicable language of the throwback rule, since the throwback provisions of UDITPA and the Illinois statute are virtually identical.

${ }^{75}$ Record, supra note 70, at C59.

76 Id. at C58-C59. 
factor in a manner consistent with such person's computation of the numerator and denominator thereof in other states employing the same factor, especially states which have adopted the Multistate Tax Compact [which embodies UDITPA]. ${ }^{77}$

Because the sales in question "were not included in the numerator of any of the states in which GTE . . . pays state income tax,"78 the Department insisted that GTE provide it with information regarding such sales in order to proceed with the audit and ultimately to adjust the sales factor appropriately. ${ }^{79}$ In July 1973, having failed to persuade the Department to abandon its request, GTE filed suit against the Director of Revenue seeking a preliminary injunction restraining the Director from requiring GTE to determine the amounts of sales in question pending resolution of the substantive issues and a permanent injunction if the court should rule for GTE on the merits. ${ }^{80}$ In addition, GTE sought a declaratory judgment that the Illinois income tax should not be construed to require inclusion of the disputed sales in the numerator of the sales factor or, alternatively, a judgment that the tax, if so construed, is unconstitutional. ${ }^{81}$ Finding that GTE failed to exhaust its administrative remedies, the trial court dismissed the complaint as premature. ${ }^{82}$

On appeal, the Appellate Court of Illinois affirmed..$^{83}$ Without reaching the merits, the court held that GTE's "failure to submit to a department audit and to otherwise exhaust its available administrative remedies makes any judicial review of this cause premature." 84 It declined to find that any of the exceptions to the exhaustion doctrine were applicable and concluded that "the interest of justice will not be served by deciding the legal and constitutional issues of this case in a factual vacuum . . . "85 GTE appealed this decision to the Illinois Supreme Court.

7 In. INC. TAX REG. \& 304-4(g), reprinted in STATE \& Loc. TAXES (III.) (P-H) \ 11,039.65 (1974); the Record recounts the discussion on this point between the Department's auditor and GTE's tax manager. Record, supra note 70, at C77-C81.

${ }^{78}$ Record, supra note 70, at C76. See also id. at C79.

70 Id. at C78-C79.

so GTE alleged that its records were not sufficient for it to determine the amounts of the sales in question and that to determine the amounts would cost "many thousands of dollars, would require months to complete, and would be a useless act if such sales [were] not required to be included in the numerator of plaintiff's sales factor." Id. at C7.

81 GTE, which filed the suit as a purported representative of a class of other persons similarly situated, also sought a determination that the suit constituted a proper class action. See id. at C2. This aspect of the litigation will not be considered further here.

Id. at C202.

38 Ill. App. 3d 910, 349 N.E.2d 654 (1976).

s Id. at 913,349 N.E.2d at 657.

ss Id. at $914-15,349$ N.E.2d at 658. 
If the Illinois Supreme Court shared the appellate court's concern about adjudicating the issues raised by $G T E$ in a "factual vacuum," the concern is belied by the court's statement of facts. Other than identifying the taxpayer as a Delaware corporation and describing in general terms the sales that were the focus of the controversy, the court made no reference to the nature of the taxpayer's activities in Illinois or elsewhere. To be sure, the court was in no position to set out the facts with particularity because of the inherent limitations of the record, ${ }^{86}$ but it could have been less laconic on this score, especially if it intended to accord any significance to facts that it did not mention-for example, that GTE's principal place of business was Illinois. ${ }^{87}$ The real explanation may well be, however, that the court simply did not believe that it was necessary to advert to any facts other than the few it recited:

It may be that all of the fact issues enumerated by defendant must be decided prior to determining plaintiff's tax liability, but they need not be decided in this case. For the purposes of this opinion it is sufficient that plaintiff alleged and defendant agreed that during the years involved plaintiff made the types of sales in question, that although they were included in the denominator of plaintiff"s sales factor as part of the "Total Everywhere," they were not included in the numerator of the sales factor as sales "Within Illinois" and that defendant has consistently maintained that the . . . sales must be included in the numerator of plaintiff's sales factor. ${ }^{88}$

Based on this view of the relevant facts and its conclusion that the suit fell within an exception to the exhaustion doctrine, ${ }^{89}$ the court turned to the merits.

\section{B. The Illinois Supreme Court's Decision on the Merits}

The court was fully aware of the significance of the issue it faced. It noted that the Illinois Income Tax Act contained the lan-

u See Part II-A supra. GTE failed to provide the information the Director claimed was necessary to conduct a proper audit. See note 80 supra.

"One might infer the existence of this fact from the court's brief discussion (and rejection) of one of the Director's arguments that was based on the premise that the taxpayer's commercial domicile was in Illinois. GTE Automatic Elec., Inc. v. Allphin, $68 \mathrm{Ill}$. 2d 326, 33637, 369 N.E.2d 841, at 846 (1977). Although the Director's argument was based on this factor, the court's rejection of it was not. One therefore cannot assume that the court gave it any weight.

ss Id. at 334, 369 N.E.2d at 845 .

sId. 
guage of UDITPA, ${ }^{90}$ it acknowledged the presence of eleven states and the Multistate Tax Commission ${ }^{91}$ as amici curiae in the case, and it observed that it was addressing a question "of first impression in the United States." "92

1. Filling the Statutory Gaps in Taxability. Looking first to the purposes of the statute, the court, without any reference to authority, assumed that the purposes of UDITPA, as reflected by the published comments of its principal author, Professor William Pierce, were those underlying the Illinois Act. ${ }^{93}$ That assumption, although plausible, should not have been made uncritically. The Illinois General Assembly, in substantially enacting UDITPA, may not have been familiar with Professor Pierce's comments. Even if it were familiar with them, the legislature may not have intended to embrace them as its own. Unfortunately, the daily journals of the Illinois Senate and House that were maintained when the legislation was enacted in 1969 are virtually useless in determining legislative intent;94 nor does the Illinois General Assembly publish committee reports. What we do have are the Commentary on the Illinois Income Tax Act and a Technical Explanation of the Act; these were furnished to members of the General Assembly with the initial income tax proposal and thus may have some bearing on legislative intent. ${ }^{85}$

In purported reliance on Professor Pierce's commentary, the court found that " $t]$ he purpose of the uniform act and article 3 of the Illinois act is to assure that $100 \%$, and no more or no less, of the business income of a corporation doing multistate business is taxed by the States having jurisdiction to tax it." meant to say that the purpose was to ensure that 100 percent of such income was taxable by the states having jurisdiction to tax it, since neither the comments of Professor Pierce nor the Technical Explanation of the Illinois Act provide any authority for the statement the

o Id.

"Id. at 334-35, 369 N.E.2d at 845. The Multistate Tax Commission is the administrative agency of the Multistate Tax Compact, which incorporates UDITPA as article IV. There are presently 19 member states and 14 associate member states of the Compact. STATE \& Loc. TAXEs (All States Unit) (P-H) II 5150 (1978). The constitutionality of the Compact was sustained in United States Steel Corp. v. Multistate Tax Comm'n, 98 S. Ct. 799 (1978). See generally HELLERSTEIN \& HELLERSTEIN, supra note 19, at 544-46 and sources cited therein.

$n 68$ Ill. 2 d at 335,369 N.E.2d at 845 .

3 Id. The court was referring to the comments by Professor Pierce in the article cited at note 7 supra.

" R. Jacobs, C. Boast, E. Hess, \& J. Sprowl, Illinois Legal Regearch Sourcebook 1-5 to 1-6 (1977).

25 These are reproduced in STATE \& Loc. TAXES (IIl.) (P-H) भा 10,901-10,966 (1973).

* 68 III. 2 d at 335,369 N.E.2d at 845 (emphasis added). 
court in fact made. Professor Pierce's commentary supports the proposition that the purpose of the Uniform Act is to insure that all of a multistate enterprise's business income is taxable somewhere;"7 the Technical Explanation may be read as consistent with that view, although it does not explicitly endorse it..8

On the assumption that the court meant to say that the intent of UDITPA's framers was to render all of a multistate enterprise's business income taxable, ${ }^{99}$ an intent that it attributed to the Illinois General Assembly without any firm basis in the legislative record, the court next had to consider the question whether the statute could be fairly read to carry out that intent with regard to the attribution of sales in the apportionment formula. The court first observed, as even the Director and amici curiae were compelled to concede, ${ }^{100}$ that the statutory language permitted the taxpayer to include the sales at issue in the denominator of the sales factor but to exclude them from the numerator. ${ }^{101}$ There was no dispute that these were the taxpayer's sales and thus includible in the denominator, ${ }^{102}$ but there was no statutory basis for including them in the numerator. They were not includible under the general rule of attribution for sales of tangible personal property because their destination was not Illinois. ${ }^{103}$ Nor was there anything in the language of the throwback rule to warrant attribution of the sales to the Illinois numerator, because the property had not been "shipped from an office, store, warehouse, factory or other place of storage in Illinois." 104

The court therefore had to confront the issue that lay at the

"See text at notes 9-10 \& 13-16 supra.

"Illinois Income Tax Act-Technical Explanation, art. 3, reprinted in STATE \& Loc. TAXes (Ill.) (P-H) I 10,953 (1973).

"If the court really meant to say that the intent of the legislature in enacting UDITPA was to assure that all of a multistate enterprise's business income is not merely taxable, but is actually taxed by the states with jurisdiction to tax it, the opinion would raise even more problems than it already does. While there may be scant support for the proposition that the Illinois legislature specifically intended to assure that a corporation was taxable on 100 percent of its income, there is none for the proposition that the legislature intended that a corporation be taxed on 100 percent of its income. Moreover, if the court's statement were taken literally, it would be impossible to reconcile with provisions of the statute, e.g., the definition of "taxability" in another state as including the situation in which another "state has jurisdiction to subject the taxpayer to a net income tax regardless of whether, in fact, the state does or does not." IrL. REv. Stat. ch. 120, \& 3-303(e) (1977). See also UDITPA \& 3; text at note 14 supra.

10 68 Ill. 2 d at 336,369 N.E. 2 d at 846.

i1' Id.

w2 ILl. REv. StaT. ch. 120, § 3-304(a)(3)(A),(B) (1977); see UDITPA $\$ \S 15,16$.

ies IL. Rev. Stat. ch. 120, \& 3-304(a)(3)(B)(i) (1977).

Ie Id. \& 3-304(a)(3)(B)(ii). 
heart of the case: ${ }^{105}$ unless the statute could be construed to attribute the sales to a state other than the state of origin or destination in which the taxpayer was not taxable, less than 100 percent of the taxpayer's income would be apportioned to a state that could tax it. As a result, the perceived purpose of UDITPA and the Illinois Act to render all of a multistate taxpayer's income taxable would be frustrated.

The court turned immediately to an examination of various alternative means of plugging the apparent "gap" in the Act's apportionment provisions without seriously considering arguments for simply allowing the gap to stand. Yet the latter approach deserved consideration.

First, given the underlying uncertainty ${ }^{108}$ of whether the Illinois legislature in fact intended to embrace the concept of "full accountability" 107 so that all of a multistate firm's income is taxable somewhere, it might well have been appropriate to allow the legislature to fill the gaps itself, to make sure that it had intended to do so in the first place. Second, although a legislature cannot be expected to have anticipated every factual variation on problems to which its legislation was directed in general terms, and courts are not to be encouraged to read statutes woodenly so as to undermine their intended purpose, the case for judicial restraint is strengthened when, as here, the statute deals with an issue with relative specificity but fails to include the case in point. Third, the court should have taken a moment to contemplate the implications of its gap-plugging approach for other sections of the Act. If there are other gaps to be filled, further questions arise as to whether the legislature intended that there be none and as to the appropriate role of the judiciary in filling them. Similar "gaps" do exist in both the property and payroll factors: mobile property may be apportioned on the basis of time or mileage factors to states in which the taxpayer is not taxable because the property is in interstate transit and forms an insufficient nexus with the state to warrant the imposition of a net income tax; ${ }^{108}$ compensation may be apportioned to states in which the

165 The court first rejected an argument by the Director predicated on language contained in the Illinois Act but not in UDITPA. The argument was based on a provision of the income tax act allocating to the state of the taxpayer's commercial domicile all "unspecified items" of income. ILL. REv. STAT. ch. 120, \& 3-301(c)(2)(B) (1977). The court found that "unspecified items" were only those items not specifically allocated or apportioned under other sections of the Act, as the taxpayer's business income plainly was. $68 \mathrm{Ill} .2 \mathrm{~d}$ at $336-37,369$ N.E.2d at 846.

10 See text at notes 94-95 supra.

10 Corrigan, supra note 44 , at 430 n.13 (1976).

106 See the regulations promulgated under the Illinois Act, ILL. REv. STAT. ch. 120, \& 3- 
taxpayer is not taxable because it engages in business only through solicitors. ${ }^{109}$ Will the court also decide how these gaps are to be filled?

In any event, given the court's disposition to fill the statutory lacunae, the question remained how to do so and on what theory. The court received a plethora of suggestions on this score. An amicus curiae brief filed by eleven states and the Multistate Tax Commission ${ }^{110}$ offered two:
Amici suggest that, in order to give effect to the manifest legis- lative intent, we should read the phrase "The property . . . shipped from an office" in section 304(a)(3)(B)(ii) [the throw- back rule] to refer to the in-State sales activity of the seller rather than just to the physical shipment of the goods. In the alternative, it is argued that in order to carry out the legislative intent, if these ... sales are properly excluded from the "Within Illinois" numerator of the sales factor, they should also be excluded from the denominator of "Sales Every- where."111

The court did not explore either of these proposals, both of which would have involved judicial tinkering with the terms of the throwback rule; it chose still another alternative urged upon it by both the Director and the amici curiae. They contended that the Director, under the general relief provision of the Act, ${ }^{112}$ had the adminis-

304(a)(1) (1977), and the Multistate Tax Compact that attempt to deal with this problem: ILInNors Income TAX REG. \& 3-304(2), (3), reprinted in StATE \& Loc. TAXes (IIl.) (P-H), IT 11,037.5-10 (1974); Multistate Tax Comm's Apportionment Rzg. IV.10.(d), reprinted in StaTE \& Loc. TAXES (All States Unit) (P-H) \ 6185 (1973). They do not completely solve the problem since they allow some property to be included in the numerator of the factor of the state to which an employee's compensation is assigned under the payroll factor. Id.; see note 109 infra.

is See ILL. REv. Stat. ch. 120, 3 3-304(a)(2)(B)(iii) (1977); UDITPA \& 13-14; text and notes at notes $39-41$ supra. Indeed, the regulations promulgated under the Multistate Tax Compact (for UDITPA), which were adopted as proposed regulations for Illinois, explicitly provide for this gap: "[C]ompensation paid to employees whose services are performed entirely in a state where the [employer] is immune from taxation, for example, by Public Law 86-272, [is] included in the denominator of the payroll factor." Multigtate TAX Comm'N Apportionment Reg. IV.13. (b), reprinted in State \& Lóc. TAXEs (All States Unit)(P-H) If 6215 (1973); Proposed Ill. Inc. TAx REg. 8 871-11(b), reprinted in STATE \& Loc. TAxzs (III.) (P-H) II 11,130 (1974). Although the Department of Revenue rescinded the Income Tax Information Bulletin announcing the issuance of the proposed regulations after Illinois withdrew from the Multistate Tax Compact, see note 74 supra, it did not rescind the regulations in question, but rather indicated that the regulations would be "revised and reissued in proposed form." Iluinois Income Tax Inrormation Bull. 1975-1, reprinted in Statz \& Loc. TAXes (Ill.) (P-H) If 11,541 (1975).

11 $68 \mathrm{Ill} .2 \mathrm{~d}$ at $334-35,369$ N.E.2d at 845.

iII Id. at $337-38,369$ N.E.2d at 846.

112 ILL. Rev. Stat. ch. 120, \& 3-304(e) (1977); UDITPA \& 18. The provisions of the Illinois 
trative authority to include in the numerator of GTE's Illinois sales factor sales in which GTE was taxable neither in the state of origin nor the state of destination. The court embraced this solution, finding that the relief provision grants the Director authority to impose any reasonable method to produce an equitable allocation and apportionment of a taxpayer's business income. The court found this use of the relief provision to be consistent with its view of the legislative intent to prevent either gaps or overlaps in the taxation of multistate business income. ${ }^{.13}$

The language of the relief provision may be broad enough to allow a reassignment of sales to the numerator of the Illinois sales factor when the taxpayer is not taxable in the state of origin or destination. To the extent that the court's assumption that the General Assembly shared the intent of the UDITPA draftsmen in enacting comparable provisions of the Illinois statute is accepted, ${ }^{114}$ however, it may be argued that the draftsmen of UDITPA designed the relief provision not to cure systemic errors in the statute, but rather to deal with unusual cases arising from the peculiarities of a particular taxpayer's business and to avoid constitutional problems. As Professor Pierce, whose comments the court invoked in its efforts to ascertain the intent underlying UDITPA and the Illinois Act, ${ }^{115}$ observed:

Of course, departures from the basic formula should be avoided except where reasonableness requires. Nonetheless, some alternative method must be available to handle the constitutional problem as well as the unusual cases, because no statutory pattern could ever resolve satisfactorily the problems for the multitude of taxpayers with individual business characteristics. ${ }^{116}$

If one declines to impute to the General Assembly the intent of the UDITPA draftsmen, the question remains, in the absence of any instructive legislative history, ${ }^{117}$ whether the court's construction of the relief provision is sound as a matter of policy. On this ground too the court's approach may be criticized. To allow the tax administrator to employ the relief provision to override the specific provisions of the sales factor because of his determination that the result

Act and UDITPA are virtually identical. See text at note 68 supra.

11368 Ill. $2 \mathrm{~d}$ at 339,369 N.E.2d at 847.

11 But see text at notes 93-98 supra.

115 See text at notes $93 \& 96$ supra.

116 Pierce, supra note 7, at 781 .

117 See note 94 supra. 
it requires is unreasonable would, it can be argued, render the specific apportionment and allocation provisions virtually meaningless since they would always be subject to revision by the administrator on the basis of a finding of unreasonableness. Hence it might be suggested, as the taxpayer unsuccessfully contended, ${ }^{118}$ that the relief provision should not be interpreted to allow the administrator to use it as a vehicle for tampering with the terms of particular provisions of the Act. Instead its use should be confined to situations in which the overall method of apportionment produces unjust results; in such cases the relief granted would be limited to separate accounting, the exclusion or inclusion of one or more factors, or the employment of some completely different method for apportioning and allocating the taxpayer's income. ${ }^{110}$

2. Constitutional Problems with the Court's Approach. Having established, at least to its own satisfaction, that the Income Tax Act could be construed to permit the inclusion of the disputed sales in the numerator of the Illinois sales factor, the court still had to confront the argument that the statute, if so construed, was unconstitutional. ${ }^{120}$ GTE argued that McLeod v. J.E. Dilworth Co., ${ }^{121}$ which held that the commerce clause precluded Arkansas from imposing a sales tax on "sales made by Tennessee vendors that are consummated in Tennessee for delivery of goods in Arkansas," 122 precluded Illinois from including sales consummated outside the state within the numerator of its sales factor. ${ }^{123}$ The court summarily rejected the argument with the remark that "[t]he formula applied here is not a sales tax, but is a method of measuring the business activity within this State of a corporation doing multistate business."124

While the court is on firm enough ground in suggesting that the constitutional standards limiting the power of the states to tax interstate sales directly are more restrictive than those limiting the power of the states to attribute sales to their respective jurisdictions

11868 Ill. $2 \mathrm{~d}$ at $338-39,369$ N.E.2d at 847.

il See Ill. Rev. Stat. ch. 120, \& 3-304(e) (1977); UDITPA \& 18, text at note 68 supra. Further support for a narrow construction of the relief provision can be found in the case law, see Deseret Pharmaceutical Co. v. State Tax Comm'n, 579 P.2d 1322 (Utah 1978), and in the literature, see, e.g., Keesling \& Warren, California's Uniform Division of Income for Tax Purposes Act (pt. I), 15 U.C.L.A. L. REv. 156, 171 (1967). Nevertheless the debate surrounding its proper construction remains open. See generally HBLLERSTEIN \& HFTLERSTKIN, supra note 19 , at $475-78$.

124 68 Ill. 2 d at 340,369 N.E.2d at 847.

121322 U.S. 327 (1944).

12 Id. at 328.

12 68 Ill. $2 \mathrm{~d}$ at 340,369 N.E.2d at 847 .

12468 Ill. 2 d at 340,369 N.E.2d at $847-48$. 
for apportionment purposes, ${ }^{125}$ this does not mean that the considerations underlying the former are irrelevant to the latter. The absence of a power in a state to tax a sale because the state lacks a connection with the transaction sufficient to justify the exercise of its taxing power may evidence a comparable absence of power in the state to include that sale in the numerator of its sales factor. Indeed, the United States Supreme Court has discredited the distinction between the subject and the measure of a tax as a basis for delineating the states' constitutional power to tax interstate commerce. ${ }^{120}$ One cannot therefore, justify a hasty dismissal of a constitutional challenge to the assignment of sales to a state for apportionment purposes on the ground that the sale is merely the measure of the tax, and its subject, such as the privilege of doing business or the firm's income, is one that lies within the state's taxing power.

The essential constitutional question at this stage of the analysis, therefore, is whether Illinois enjoyed a sufficient nexus with sales whose origin and destination lay elsewhere, to warrant the use of such sales as a basis for apportioning income to Illinois. The court never confronted the substance of this question, in part because it was in no position to do so:

On this record we cannot determine what plaintiff's business activity in this State has been with respect to these . . . sales, and this can be determined in a hearing before the Department. We hold, however, that the mere fact that both the origin and destination of these sales were outside Illinois does not show that there were not sufficient local activities within Illinois to form a sufficient nexus between the Illinois income tax and transactions in Illinois by which the tax is measured. ${ }^{127}$

In effect, the court ruled that GTE had the burden to come forward with evidence that there was insufficient nexus, a burden it had failed to carry on a record wanting of critical facts.

But this did not dispose of GTE's constitutional challenge. There was still the question whether inclusion of the sales would subject GTE to a multiple tax burden not borne by local business,

${ }^{125}$ Compare McLeod v. J.E. Dilworth Co., 322 U.S. 327 (1944) with International Harvester Co. v. Evatt, 329 U.S. 416 (1947).

123 See Department of Revenue v. Association of Wash. Stevedoring Cos., 98 S. Ct. 1388 (1978); Complete Auto Transit, Inc. v. Brady, 430 U.S. 274 (1977); W. Hellerstein, State Taxation and the Supreme Court: Toward a More Unified Approach to Constitutional Adjudication?, 75 Mrch. L. REv. 1426, 1441-46 (1977); W. Hellerstein, supra note 41, at 17688.

1768 Ill. $2 \mathrm{~d}$ at 340,369 N.E.2d at 848. 
in violation of established commerce clause principles. ${ }^{128}$ The "multiple burdens" test as a criterion for determining the constitutionality of a state tax on interstate commerce was developed by Justices Stone and Rutledge in the late 1930s as a practical and more liberal alternative to the formal and restrictive "directindirect" burdens approach that dominated the Court's thinking in the early part of the century. ${ }^{129}$ Western Live Stock $v$. Bureau of Revenue $^{130}$ is generally regarded as the seminal opinion reflecting the new doctrine. In that case, which involved a New Mexico gross receipts tax on a magazine publisher, Justice Stone found the tax reasonable and supported by "the practical needs of a taxing system which, under constitutional limitations, must accommodate itself to the double demand that interstate business shall pay its way, and that at the same time it shall not be burdened with cumulative exactions which are not similarly laid on local business."131 Justice Stone saw no danger of other states burdening the interstate distribution of the magazine by imposing similar taxes on the appellant. ${ }^{132}$

Justice Rutledge, whose opinions gave further life to the doctrine, expounded his views most clearly in his separate opinion in a trilogy of cases that established the underlying constitutional principles in the sales and use tax area: ${ }^{133}$

[T] he state may not impose certain taxes on interstate commerce, its incidents or instrumentalities, which are no more in amount or burden than it places on its local business, not because this of itself is discriminatory, cumulative or special or would violate due process, but because other states also may have the right constitutionally, apart from the commerce clause, to tax the same thing and either the actuality or the risk of their doing so makes the total burden cumulative, discriminatory or special. ${ }^{134}$

The multiple burdens doctrine continues to be a cornerstone of con-

123 See text at notes 168-177 infra with respect to the impact of the Supreme Court's decision in Moorman Mfg. Co. v. Bair, 437 U.S. 267 (1978), upon these principles.

12 See Hellerstein \& HeLlerstein, supra note 19, at 239-44.

130303 U.S. 250 (1938).

ist Id. at $258,260$.

132 Id.

133 McLeod v. J.E. Dilworth Co., 322 U.S. 327 (1944); General Trading Co. v. State Tax Comm'n, 322 U.S. 335 (1944); International Harvester Co. v. Department of Treasury, 322 U.S. 340 (1944). Justice Rutledge wrote a single opinion to concur in McLeod and General Trading and to dissent in International Harvester. 322 U.S. at 349-62.

is 322 U.S. at 358 (citation omitted). 
stitutional doctrine with regard to state taxation of interstate commerce, ${ }^{135}$ although its role in the apportionment context has recently been narrowed. ${ }^{138}$

The Illinois court's response to GTE's multiple taxation claim (which was couched in the language of "double taxation") was succinct: "It is only those out-of-State . . . sales in which plaintiff is not taxable either in the State of origin or destination that are being assigned to Illinois, and this obviously cannot result in double taxation." 137 Taken on its face, the statement simply is not true. From the mere fact that neither the state of the sales' origin nor that of their destination can tax GTE, one can hardly infer that Illinois has an exclusive right to assign the sales to itself for apportionment purposes. Indeed, from the court's reasoning, it would seem that any state in which GTE was taxable and which had a sufficient nexus with the sales at issue could likewise include these sales within the numerator of its sales factor. ${ }^{138}$ This could result in multiple taxation of the most manifest kind, thereby placing the multistate business at a disadvantage to intrastate business.

Nevertheless, although the court's opinion cannot withstand analysis in this respect, its decision does not necessarily raise constitutional problems. If one were to limit the assignment of sales that have their origin and destination in states in which GTE is not taxable to a single state in which GTE is taxable, the multiple burdens problem would disappear. In this instance, Illinois was GTE's principal place of business, although the court's opinion does not mention this fact. ${ }^{139}$ Whatever questions one may raise from the standpoint of policy or statutory intent, ${ }^{140}$ if the decision in GTE is taken to mean that sales not taxable elsewhere may be assigned to the sales factor numerator of the state in which the taxpayer has its principal place of business, the decision would appear to be constitutionally unobjectionable.

A second basis for finding the court's decision constitutionally acceptable is to read it as saying no more than that the taxpayer has the burden of proving its case. Under this view, even if a risk of

13s See Department of Revenue v. Association of Wash. Stevedoring Cos., 435 U.S. 734 (1978); Complete Auto Transit, Inc. v. Brady, 430 U.S. 274 (1977).

134 See Moorman Mfg. Co. v. Bair, 437 U.S. 267 (1978); text at notes 159-177 infra.

13768 IIl. $2 \mathrm{~d}$ at 341,369 N.E.2d at 849.

iss More precisely, this claim could be made by states with respect to which the taxpayer had failed to carry its burden of demonstrating an insufficient nexus between the state and the sales at issue.

13 Record supra note 70, at C2, C47; 38 IIl. App. 3d 910, 911, 349 N.E.2d 854, 855.

16 See text at notes 144-158 infra. 
multiple taxation arises from allowing any state with a sufficient nexus with the taxpayer and its sales to assign the sales to itself for apportionment purposes, unless the taxpayer can demonstrate that it has in fact been subjected to multiple taxation, the problem is not one of constitutional magnitude. Whether this represents a proper understanding of the multiple taxation doctrine is a question that is considered below ${ }^{141}$ in light of the Supreme Court's recent decision in Moorman Manufacturing Co. v. Bair. ${ }^{142}$ For the moment, it is sufficient to observe that if the Illinois court's opinion were so read, constitutional concerns it might have raised would be considerably diminished, particularly in view of GTE's concession that it had not included the disputed sales in the numerator of any state in which it pays income tax. ${ }^{143}$

\section{Suggestions FOR A Revised OpINION}

The problem posed by the GTE case calls for a solution more sensitive to both statutory and constitutional considerations than that offered by the Illinois Supreme Court. Although the court's approach, if viewed charitably, is by no means indefensible, its failure to clarify its position on critical issues of law and fact makes it especially important to delineate guidelines for future cases involving the questions raised by $G T E$.

\section{A. The Statute}

UDITPA does not specifically assign to the sales factor numerator of any state receipts from a taxpayer's sales of tangible personal property when the taxpayer is not taxable in the state of origin or destination. If this statutory gap is not closed, some of the income of a taxpayer making such sales will necessarily escape taxation. As suggested above, ${ }^{144}$ there is a case to be made for allowing the gap to stand in the absence of any legislative history indicating an intent by the state legislature enacting UDITPA to adopt Professor Pierce's views regarding "full accountability." There are also principled objections to the use of the relief provision as a vehicle for modifying the basic provisions of the statute under these circumstances. ${ }^{145}$ Although these are legitimate criticisms of the approach taken by the Illinois Supreme Court and are worthy of more atten-

\footnotetext{
14 See text at notes 159-177 infra.

Is 437 U.S. 267 (1978).

is See text at note 78 supra.

"il See text at notes 106-109 supra.

145 See text at notes 114-119.
} 
tion than the court accorded them, it is also fair to say that they are not overwhelming. Hence, assuming that the legislative record is silent on these questions, a court may with some justification conclude-perhaps from other provisions of the statute, perhaps from material made available to the state legislature-that the enactment of UDITPA reflects a legislative intent to render all of a multistate firm's income taxable and that the relief provision may be employed to achieve that purpose. If a court makes such a judgment, the question becomes how and on what basis to assign the disputed sales.

The Illinois Supreme Court permitted the assignment of such sales to Illinois, under the authority of the statutory relief provision, "to effectuate the legislative intent of avoiding either an overlap or gap in allocating and apportioning all the business income from plaintiff's multistate operations." ${ }^{146}$ But the court does not tell us-and there is nothing in its opinion that reveals-why this intent is better effectuated by assigning such sales to Illinois rather than to some other jurisdiction in which GTE is taxable. ${ }^{147}$ Although we might speculate from the record about the factual premises underlying the Ilinois court's decision, ${ }^{148}$ an inquiry into the proper basis for assigning the sales in question is appropriate.

The attribution of receipts from sales of tangible personal property to the sales factor numerator on a destination basis is designed to reflect the contribution made by the market state to the production of a firm's apportionable income. When the taxpayer is not taxable in the state of destination, the goal of rendering all of a taxpayer's income taxable justifies adoption of a throwback of such receipts to the state of origin. Although this requires a deviation from a wholly consistent approach to the apportionment of a taxpayer's income, ${ }^{149}$ the formula nevertheless attributes the sale to a jurisdiction with which the sale has a palpable connection. Reassignment to the state of origin thus continues to reflect the contribu-

14 68 IIl. 2d at 339,369 N.E.2d at 847.

147 My assumption here is that UDITPA's intent is to attribute such sales to one jurisdiction only. One could argue, however, that until the taxpayer demonstrates that assignment of such sales to the jurisdiction seeking to include them in its sales factor numerator will in fact subject the taxpayer to taxation on more than 100 percent of its income, assignment to any state enjoying a sufficient nexus with the taxpayer and the sales would be consistent with the statute's purpose. If this view is adopted, the question becomes one of determining priorities among attribution rules rather than choosing a particular rule of attribution. The considerations discussed in the text would seem to be as relevant to the former inquiry as to the latter.

14 See text at notes 86-87 supra.

14 See text at notes 59-60 supra. 
tion of a state to the production of the firm's income on the basis of the state's relationship to the sale.

When the taxpayer is taxable neither in the state of destination nor in the state of origin, "full accountability" continues to justify the assignment of the sale to a jurisdiction in which the taxpayer is taxable. Since the purpose of the sales factor would appear to be most faithfully served if the sales were assigned to a state which has some nexus with them, the sales activity test ${ }^{150}$ or the sales office negotiation test ${ }^{151}$ would then be the most logical choices for assignment of receipts.

In the unlikely event that the taxpayer is not taxable either in the state in which the sales employees principally conduct their selling activities (the "sales activity test") or in the state in which the sale was principally negotiated (the "sales office negotiation test"), ${ }^{152}$ the question would remain where to assign such sales to assure that all of the taxpayer's income is taxable somewhere. One might suggest that in such cases the sales should be assigned to the taxpayer's principal place of business or commercial domicile, ${ }^{153}$ where it would be taxable. This solution might find some justification in administrative convenience, but it in no way serves the purpose of the sales factor, which is to recognize the contribution of states having some special connection with, and making some contribution to, sales producing the taxpayer's income. On the other hand, it could be contended that the only alternative which assures that a taxpayer is taxable on all of its income-the throwout rule ${ }^{154}$-is no more acceptable from a policy standpoint. ${ }^{155}$ The effect

150 See text at note 32 supra. This seems to be the position taken by the Multistate Tax Commission in its implementing regulations for UDITPA under the Multistate Tax Compact. Multistate Tax Comm'n Apportionment Reg. IV.16.(a)(B)(7), reprinted in State \& Loc. TAXes (All States Unit) (P-H) If 6265.15 (1973). See also Proposed Itl. Inc. TAX Rzg. \$ 871 12(c)(1)(G), reprinted in STATE \& Loc. TAXES (Ill.) (P-H) ๆ 11,135.110-.115 (1974); notes 74 and 109 supra.

$13 t$ See text at note 32 supra.

152 Such activities would in most instances exceed the minimum threshold established by Pub. L. No. 86-272. Act of Sept. 14, 1959, Pub. L. No. 86-272, 8101 , 73 Stat. 555 (codified at 15 U.S.C. $\$ 381$ (1976)).

135 UDITPA and the Illinois Income Tax Act define commercial domicile as "the principal place from which the trade or business of the taxpayer is managed." UDITPA \& 1(b); ILL. REv. Stat. ch. 120, \& 15-1501(a)(2) (1977).

is See p. 775 supra.

135 The discussion in the text proceeds on the assumption that the four basic tests for assigning receipts from sales of tangible personal property-destination, origin, sales activity, and sales office negotiation-exhaust the possibilities for attribution of sales based on the connection of the taxing state with the sale. One could, however, suggest additional alternatives that might be distinguishable from the four mentioned: for example, the place where the order for a sale is received or where negotiating personnel are located. See STATE \& Loc. 
of adopting the throwout rule is to divide among all the states in which the taxpayer is taxable the portion of the taxpayer's income that is presumptively generated by the sales "thrown out," even if these states have no connection whatsoever with these sales. The commercial domicile, as the nerve center of the corporate body, has at least an attenuated connection with all of a taxpayer's operations, and it is arguably more rational to apportion income generated by such sales to it than to states that cannot claim even that remote connection.

While the question is close, the throwout rule appears to me to be a more acceptable alternative than the principal place of business rule, assuming that the preferred solution-assignment to a state with some direct connection with the sale itself-would not assure that all of a taxpayer's sales are assigned to a state in which it was taxable. This may involve a more significant deviation from the theory underlying the inclusion of a sales factor in the apportionment formula than would assignment to the commercial domicile. The justification for employing an apportionment formula, however, stems from our inability to identify directly the precise source of a multistate firm's business income on a geographical basis, ${ }^{156}$ so that we are necessarily operating in an area in which uncertainty must be tolerated. ${ }^{157}$ It is therefore reasonable to let distributive considerations play a role in the choice of a rule for apportioning receipts when theoretical considerations do not plainly require a particular result. Inasmuch as the commercial domicile is already the residuary beneficiary of UDITPA's provisions relating to the allocation of certain non-business income from tangible personalty, patents, and copyrights when the taxpayer is not taxable in the state in which the property, patent, or copyright is utilized or located, ${ }^{158}$ it seems fair to let other states increase their tax bases by a portion of the residue of the taxpayer's business income when there is no compelling reason to assign that residual income to the state of commercial domicile.

TAXEs (All States Unit) (P-H) I 1047 (1977). Hence, before proceeding to consider less desirable alternatives, one should perhaps explore the possibility of assigning the receipts ${ }^{\text {in }}$ question on other bases that reflect a relationship between the taxing state and the sale.

136 Underwood Typewriter Co. v. Chamberlain, 254 U.S. 113, 120-21 (1920); G. Altman

\& F. Keesling, Allocation of Income in State Taxation 107 (2d ed. 1950).

${ }_{157}$ Moorman Mfg. Co. v. Bair, 437 U.S. 267 (1978).

138 UDITPA $\S \S 5(\mathrm{~b}), 6(\mathrm{~h}), 8(\mathrm{a})$. 


\section{B. The Constitution.}

The critical constitutional problem raised by the $G T E$ case involves the nature and extent of the restraints that the multiple taxation doctrine imposes on the assignment of sales to a state for apportionment purposes. Of central importance in this context is whether the doctrine precludes a state from subjecting interstate business to the risk of multiple taxation not borne by local business or whether it merely protects the multistate taxpayer from in fact being taxed on more than 100 percent of its tax base.

The implications of the doctrine are significantly different depending on which view of its scope is adopted. If the "risk" criterion is deemed controlling, no jurisdiction could constitutionally adopt a rule for assignment of sales that, if adopted by other states, would result in subjecting the taxpayer to a levy on more than 100 percent of its tax base. Indeed, it might even be contended under this view of the multiple taxation doctrine that the Constitution would require a uniform rule for assignment of sales, since nonuniformity in itself could subject the multistate business to the risk of multiple taxation. If, on the other hand, the operation of the multiple taxation doctrine depends on a demonstration by the taxpayer that more than 100 percent of its tax base has actually been subjected to taxation, any rule adopted by a state for assignment of sales would remain invulnerable to attack until the requisite factual showing were made.

As originally formulated, the multiple taxation doctrine appeared to be couched in the language of possibility rather than certainty; constitutionality depended on whether multiple burdens were capable of being imposed, not whether they actually had been. ${ }^{159}$ In subsequent cases upholding state taxes over the objection that they subjected interstate businesses to the risk of multiple taxation, however, the Court seemed to require taxpayers to demonstrate something more to support their claims. In Northwestern States Portland Cement Co. v. Minnesota, ${ }^{180}$ the Court noted that "[t]here is nothing to show that multiple taxation is present. We cannot deal in abstractions. In this type of case the taxpayers must show that the formula places a burden upon interstate commerce

139 See Central Greyhound Lines, Inc. v. Mealey, 334 U.S. 653, 663 (1948); Joseph v. Carter \& Weekes Stevedoring Co., 330 U.S. 422, 427 (1947), overruled on other grounds, Department of Revenue v. Association of Wash. Stevedoring Cos., 435 U.S. 734 (1978); Gwin, White \& Prince, Inc. v. Henneford, 305 U.S. 434, 444 (1939); J.D. Adams Mfg. Co. v. Storen, 304 U.S. 307, 311 (1939). See also text at note 134 supra.

16 358 U.S. 450 (1959) (together with Williams v. Stockham Valves \& Fittings, Inc.). 
in the constitutional sense."'181 In General Motors Corp. $v$. Washington, ${ }^{162}$ the Court reiterated this position ${ }^{163}$ over the vigorous dissent of Justice Goldberg, who remarked that "if there is to be a limitation on the taxing power of each of these States, that limitation surely cannot be on a first-come-first-tax basis."164 This trend was short-lived. Several years later the Court once again reversed field, striking down a tax in part on the ground that it subjected the taxpayer to the "risk of a double tax burden"165 without a word about the taxpayer's burden of showing it had actually been subjected to double taxation. From this, one state court concluded that "the 'risk' rule for multiple taxation remains 'the' rule."160

This was the way the law appeared to stand when the Illinois Supreme Court summarily rejected GTE's claim that assignment to Illinois of the disputed sales would violate commerce clause strictures proscribing double taxation. As indicated above, ${ }^{107}$ there was nothing in the Illinois Supreme Court's opinion to suggest the basis for the assignment of the sales to Illinois; and its reasoning could therefore have justified the assignment of such sales to any number of jurisdictions subjecting the taxpayer to a clear risk of multiple taxation.

Whatever objections on this score might have been leveled against the GTE opinion when it was handed down, analysis of the multiple taxation doctrine's application to the apportionment of income from interstate business must now take account of the recent decision of the United States Supreme Court in Moorman Manufacturing Co. v. Bair, ${ }^{188}$ which has cast new light on the issue. In Moorman, the Court sustained the constitutionality of Iowa's single-factor sales formula for apportioning corporate income. The taxpayer manufactured and sold animal feeds. All of its products sold to Iowa customers were manufactured in Illinois. The taxpayer sought to demonstrate that Iowa's single-factor sales formula for

iI Id. at 463. The taxes at issue in these cases, which were net income taxes apportioned by a three-factor formula, may have been viewed by the court as inherently incapable of subjecting interstate commerce to a risk of multiple taxation not borne by local commerce. See id. at 462.

862377 U.S. 436 (1964).

its Id. at 449.

in Id. at 458 .

tus Evco v. Jones, 409 U.S. 91, 94 (1972) (quoting J.D. Adams Mfg. Co. v. Storen, 304 U.S. 307, 311 (1939)).

16s Michigan Fruit Canners, Inc. v. Department of Treasury, 53 Mich. App. 1, 7, 218 N.W.2d 385, 388 (1974). See also Standard Pressed Steel Co. v. Department of Revenue, 419 U.S. 560, 563 (1975); W. Hellerstein, supra note 41, at $175 \mathrm{n} .133$ (1976).

in See text at notes 136-143 supra.

iss 437 U.S. 267 (1978). 
apportioning net income, when considered in conjunction with Illinois' three-factor formula of property, payroll, and sales, subjected income derived from its Iowa sales to duplicative taxation in violation of the commerce clause.

The Court's reasoning in rejecting this claim is most instructive. First, the Court declared that the taxpayer had failed to establish the "essential factual predicate"189 for a claim of duplicative taxation:

Appellant's net income during the years in question was approximately $\$ 9$ million. Since appellant did not prove the portion derived from sales to Iowa customers, rather than sales to customers in other States, we do not know whether Illinois and Iowa together imposed a tax on more than $100 \%$ of the relevant net income. ${ }^{170}$

It was not enough to show that the application of two inconsistent apportionment formulas to the same tax base could produce taxation of more than 100 percent of "relevant net income"-here, income generated to some significant extent in Iowa or Illinois. It was necessary to show, presumably by separate accounting for the income on a geographical basis, that this was in fact the case. ${ }^{171}$

Notwithstanding this flaw in the taxpayer's case, the Court proceeded to address the constitutional questions raised by the two conflicting formulas on the assumption that they produced "some overlap"172 in the taxation of Moorman's income. The taxpayer had contended that "to the extent this overlap is permitted, the corporation that does business in more than one State shoulders a tax burden not shared by those operating entirely within a State,"173 and it suggested that the commerce clause precluded such a result. The Court responded that "[t]he only conceivable constitutional basis for invalidating the Iowa statute would be that the Commerce Clause prohibits any overlap in the computation of taxable income by the States."174 But the Court noted that because the risk of such

i' Id. at 276 .

in' Id.

171 The taxpayer might also prevail if it could show, by separate accounting, "that a significant portion of the income attributed to Iowa in fact was generated by its Illinois operations," thus proving "by 'clear and cogent evidence' that the income attributed to the State is in fact "out of all proportion to the business transacted . . . in that State." "Id. at 2345, quoting from Hans Rees' Sons, Inc. v. North Carolina, 283 U.S. 123, 134 (1931). See generally HELLERSTEIN \& HRLLRRSTEIN, supra note 19 , at $432-37$ and sources cited therein.

172437 U.S. at 277.

173 Id.

in Id. at 278 . 
overlap may exist any time a multistate firm does business in states having different division of income rules, a constitutional requirement of precisely apportioned income would have unacceptably broad consequences. The taxpayer's view of the Constitution, the Court warned, would result in "extensive judicial lawmaking"; the Court would be required to define each category in the three-factor formula to remove any possibility of duplicative taxation.

It would be necessary for this Court to prescribe a uniform definition of each category in the three-factor formula. For if the States in which a corporation does business have different rules regarding where a 'sale' takes place, and each includes the same sale in its three-factor computation of the corporation's income there will be duplicative taxation despite the apparent identity of the formulas employed. ${ }^{175}$

The Court concluded that "the legislative power granted to Congress by the Commerce Clause of the Constitution would amply justify the enactment of legislation requiring all States to adhere to uniform rules for the division of income," and such policy decisions should be made by that body to which they are constitutionally committed. ${ }^{176}$ In thus rejecting the taxpayer's invitation to forge the commerce clause into a tool for constitutionalizing division of income problems, the Court made it plain that, in this context, the multiple taxation doctrine has a more limited role to play than once might have been envisioned.

For present purposes, the question is where Moorman leaves the constitutional issue raised by GTE. At the very least, it suggests that the Illinois Supreme Court was on firm constitutional ground if its opinion is read as rejecting the taxpayer's claim of multiple taxation (1) because it failed to show that more than 100 percent of its relevant income was in fact being taxed as a result of the attribution of the disputed sales to Illinois or (2) because, even assuming some overlap in the taxation of its income, the overlap was due only to the leeway the Constitution accords the states in designing formulas for apportioning net income.

There is, however, a problem presented by GTE that was not presented by Moorman and concerning which Moorman's implications are unclear. In Moorman, the Court held that the commerce clause did not require uniform rules for the division of income and that whatever duplicative taxation may result merely from the lack

175 Id. (emphasis added) (footnote omitted).

${ }^{17 \pi}$ Id. at 280. 
of uniformity does not raise an issue of constitutional magnitude. Yet the Court explicitly pointed out that if either the Iowa or Illinois apportionment formula had been adopted universally, no problems of multiple taxation would arise. ${ }^{177}$ In GTE, however, the Illinois Supreme Court's opinion arguably sustains a method for apportioning net income which, if adopted universally, would in many instances produce multiple taxation. For if every state that had a sufficient nexus with GTE and its sales included in its sales numerator sales whose origin and destination were states in which GTE was not taxable, the likely result would be to subject GTE to taxation on more than 100 percent of its income. Moorman does not explicitly sanction-and, in my view, should not be read to countenancesuch a result.

Although Moorman emphasized the importance of establishing the "essential factual predicate" for a claim of multiple taxation as well as the constitutional tolerance for duplicative taxation that is solely a function of nonuniformity, it did not put its imprimatur on a formula that by its very nature created the risk of multiple taxation. A state may, after Moorman, legitimately insist that a taxpayer demonstrate that a challenged apportionment will in fact subject it to multiple taxation. Once that showing has been made, however, a state should not be able to rely on the fact that duplicative taxation may be an intrinsic feature of a system characterized by nonuniformity when the duplication is created not by such nonuniformity but rather by a formula which, even if adopted by other states, would subject the interstate business to a tax burden not borne by its local competitor. Only if such a limitation is read into the Illinois Supreme Court's opinion in GTE would it comport with sound constitutional doctrine.

\section{Conclusion}

In $G T E$, the Illinois Supreme Court construed UDITPA with the expressed intent of fulfilling the Act's purpose of assuring that 100 percent of the income of a multistate business is taxable by the states. In so doing, it wrote an opinion that might be read to countenance results that find no support in UDITPA and raise serious constitutional problems as well. Although the United States Supreme Court's recent opinion in Moorman makes it clear that the states are to be accorded the utmost leeway in apportioning income from interstate business, it does not suggest that the Constitution

17 Id. at 277. 
tolerates multiple taxation resulting from a state's apportionment formula which, by its terms, would lead to multiple taxation if adopted by other states. The Illinois Court's opinion in GTE should be read with this limitation in mind. 